\title{
Zmiany pochodzenia naczyniowego w tkankach przyzębia okołowierzchołkowego - diagnostyka kliniczna i radiologiczna
}

\author{
Lesions of vascular origin in periapical periodontium — clinical diagnosis \\ and diagnostic imaging
}

\author{
${ }^{1}$ Katedra i Klinika Stomatologii Zachowawczej i Endodoncji, \\ Uniwersytet Medyczny im. Karola Marcinkowskiego w Poznaniu \\ 2 Zakład Radiologii Klinicznej, Katedra Radiologii Ogólnej i Zabiegowej, \\ Uniwersytet Medyczny im. Karola Marcinkowskiego w Poznaniu
}

DOI: http://dx.doi.org/10.20883/df.2020.5

\begin{abstract}
STRESZCZENIE
Proces diagnostyki i leczenia zmian w okolicy okołowierzchołkowej zębów stanowi istotne zagadnienie kliniczne współczesnej endodoncji. Zmiany tego rodzaju są często wykrywane przypadkowo przy wykonywaniu innych procedur diagnostycznych, a nieleczone w sposób odpowiedni mogą prowadzić do rozległej destrukcji tkanek w obrębie twarzoczaszki oraz powikłań zagrażających zdrowiu i życiu pacjentów. Ze względu na etiologię zmiany te można podzielić na zębopochodne i niezębopochodne. W pracy przedstawiono współczesny stan wiedzy dotyczący stanów patologicznych w tkankach okołowierzchołkowych oraz diagnostykę różnicową (kliniczną oraz radiologiczną) zmian niezębopochodnych pochodzenia naczyniowego, objawiających się w sposób do złudzenia przypominający przewlekłe zapalenie tkanek okołowierzchołkowych.
\end{abstract}

Słowa kluczowe: endodoncja, choroby okolicy okołowierzchołkowej, nowotwory głowy i szyi.

\section{ABSTRACT}

Diagnostics and treatment of lesions located in apical periodontium constitutes an important clinical issue in contemporary endodontics. Such lesions are often diagnosed accidentally during other diagnostic procedures. If they are left untreated, their development may lead to extensive tissue destruction within the head and neck. According to their aetiology, they can be classified into odontogenic and non-odontogenic lesions. The paper discusses contemporary state of knowledge concerning pathology within periapical tissues, and differential diagnostics (clinical and radiographic) of vascular non-odontogenic lesions that may mimic chronic apical periodontitis.

Keywords: endodontics, periapical diseases, head and neck neoplasms.

\section{Wstęp}

Diagnostyka i leczenie zmian patologicznych w okolicy przyzębia okołowierzchołkowego jest istotnym problemem klinicznym współczesnej endodoncji [1]. Zmiany te są często wykrywane przypadkowo podczas rutynowego badania stomatologicznego obejmującego również wykonanie zdjęć rentgenowskich, a jedynie w niewielkim odsetku przypadków ich rozwój wiąże się z gwałtownym przebiegiem skłaniającym pacjenta do zgłoszenia się do poradni stomatologicznej [2]. Ze względu na ich etiologię, zmiany te można podzielić na dwie bardzo obszerne grupy: zębopochodne oraz niezębopochodne. W przypadku zmian pochodzenia zębowego, w piśmiennictwie zarówno polskim, jak i światowym dostępnych jest wiele systemów klasyfikacji omawianych schorzeń, a zasadniczo dzieli się je według przebiegu na stany związane z przekrwieniem tkanek okołowierzchołkowych, zapalenia ostre i przewlekłe oraz zmiany typu torbieli, przez niektórych autorów traktowane jako specyficzny obraz przewlekłego stanu zapalnego [3]. Głównym czynnikiem etiologicznym rozwoju patologii $w$ tkankach okołowierzchołkowych jest stan zapalny w obrębie miazgi zęba. W przypadku przekrwienia tkanek okołowierzchołkowych czy ostrych stanów zapalnych zachowuje ona żywotność, jednak przy niepodjęciu odpowiedniego leczenia, po wniknięciu drobnoustrojów i obumarciu tkanki w komorze i kanałach korzeniowych, docho- 
dzi do rozwoju odczynu zapalnego w odpowiedzi na bodźce drażniące - zarówno mikroorganizmy jamy ustnej, jak również bodźce autoimmunologiczne, co spowodowane jest tym, że miazga martwa staje się autoantygenem dla ustroju [4].

\section{Procesy zapalne w przyzębiu okołowierzchołkowym}

Większość przypadków zapalenia tkanek okołowierzchołkowych przebiega bezobjawowo, a podjęcie leczenia następuje albo wskutek rozpoznania w trakcie rutynowego badania radiologicznego i stomatologicznego, albo po zgłoszeniu się pacjenta w stanie zaostrzenia lub w wypadku rozwinięcia się powikłań niepokojących pacjenta. Objawami klinicznymi charakterystycznymi dla zapaleń ostrych lub stanów zaostrzeń zmian rozwijających się przewlekle są wrażliwość na opukiwanie pionowe zęba, uczucie wysadzania zęba z zębodołu oraz ból samoistny. Większość przypadków zmian przewlekłych nie manifestuje się klinicznie w sposób charakterystyczny, pacjenci mogą niekiedy zgłaszać uczucie okresowego obrzęku czy wrażliwości, jednak są to odczucia o nieokreślonym charakterze, nieutrudniające codziennego funkcjonowania i rzadko wiązane z przyczynami pochodzenia zębowego [5].

Obraz radiologiczny zmian pochodzenia zębowego zależy od stadium rozwoju zmian [6]. W zapaleniach ostrych nie obserwuje się wyraźnych i uchwytnych zmian w obrazie rtg. Według niektórych autorów może widoczne być wówczas poszerzenie szpary ozębnej, jednak jest to kryterium, dla którego nie ma określonej normy lub wartości referencyjnej, tak więc w sposób bezpośredni trudno jest określić stan tej struktury. Inaczej sytuacja przedstawia się w przypadku zmian o charakterze przewlekłym. Ze względu na długo trwający rozwój, wskutek działania mikroorganizmów oraz ich produktów przemiany materii dochodzi do niszczenia kości w okolicy okołowierzchołkowej. Na zdjęciu rtg widoczne jest wówczas wyraźne przejaśnienie, świadczące o aktywnych procesach resorpcyjnych tkanki kostnej.

Istotną rolę $w$ procesie diagnostycznym odgrywają metody radiologiczne. Ze stosowanych w rutynowej diagnostyce stomatologicznej projekcji, do wykrywania obecności zmian typu przewlekłego zapalenia tkanek okołowierzchołkowych stosuje się zdjęcia zębowe i pantomograficzne (ryciny 1 i 2) $[5,7]$. Opublikowane dotąd badania wskazują na to, że obie metody są skuteczne w identyfikacji ognisk zapalnych i nie obserwuje się dużych różnic pomiędzy nimi (tabela 1).

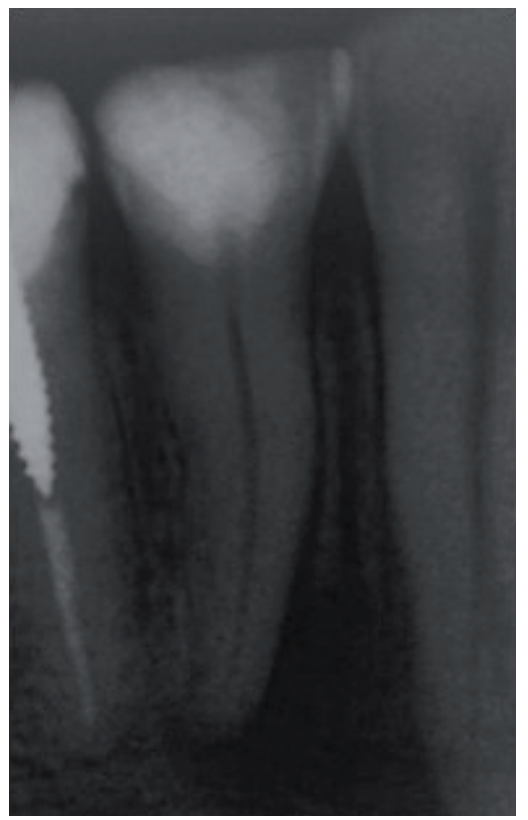

Rycina 1. Rtg zębowe. Widoczna zmiana typu przewlekłego zapalenia tkanek okołowierzchołkowych wokół pierwszego przedtrzonowca żuchwy spowodowana martwicą miazgi wskutek nieodpowiedniego wypełnienia ubytku próchnicowego

Figure 1. Periapical $x$-ray. Chronic periapical periodontitis lesion at the first mandibular premolar caused by pulp necrosis due to deep caries

W ostatnich latach wzrosła również częstotliwość wykorzystywania w diagnostyce stomatologicznej tomografii stożkowej (ang. cone beam computed tomography - CBCT) (rycina 2). Jest to metoda umożliwiająca trójwymiarową ocenę lokalizacji i wymiarów zmian patologicznych $[8,9,10]$.

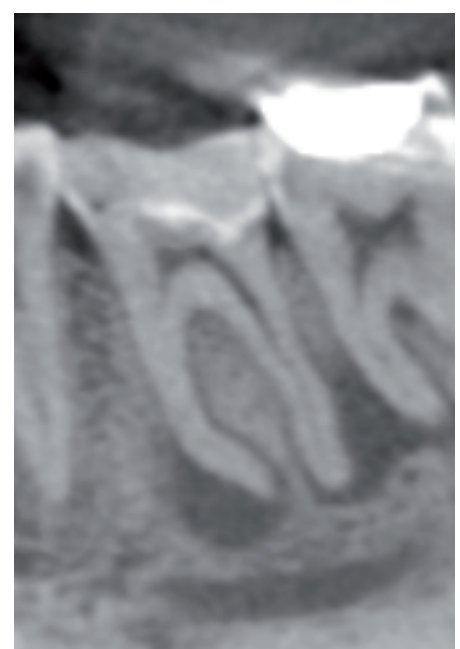

Rycina 2. Skan tomografii CBCT. Obraz przewlekłego zapalenia tkanek okołowierzchołkowych spowodowanego martwicą miazgi pierwszego trzonowca żuchwy

Figure 2. CBCT scan. Chronic periapical periodontitis lesion at the first mandibular molar caused by pulp necrosis 
Tabela 1. Wartość diagnostyczna różnych badań radiologicznych w diagnostyce przewlekłego zapalenia tkanek okołowierzchołkowych wg piśmiennictwa

Table 1. Diagnostic value of different diagnostic imaging methods used for the diagnostics of periapical periodontitis, according to literature

\begin{tabular}{|l|l|c|c|c|c|}
\hline \multirow{2}{*}{ Rodzaj badania } & \multicolumn{1}{|c|}{ Autor badań } & Czułość & Swoistość & $\begin{array}{c}\text { Pozytywna wartość } \\
\text { predykcyjna }\end{array}$ & $\begin{array}{c}\text { Negatywna wartość } \\
\text { predykcyjna }\end{array}$ \\
\hline \multirow{5}{*}{ Rtg zębowe } & Patel i wsp. (2009) & 24 & 100 & 100 & 38 \\
\cline { 2 - 6 } & Sogur i wsp. (2009) & 80,33 & 67 & 87 & 52 \\
\cline { 2 - 6 } & Sullivan i wsp. (2000) & 62,70 & 41,66 & 80,78 & 21,24 \\
\cline { 2 - 6 } & Wallace i wsp. (2001) & 34,5 & 72,5 & 82 & 21 \\
\cline { 2 - 6 } & Estrela i wsp. (2008) & 55 & 98 & 98 & 35 \\
\hline \multirow{2}{*}{ Rtg pantomograficzne } & Estrela i wsp. (2008) & 28 & 100 & 99 & 100 \\
\hline \multirow{4}{*}{ CBCT } & Liang i wsp. (2014) & 100 & 100 & 100 & 76 \\
\cline { 2 - 6 } & Lennon i wsp. (2011) & 91 & 73 & 89,1 & 100 \\
\cline { 2 - 6 } & Patel i wsp. (2009) & 100 & 100 & 100 & 70 \\
\cline { 2 - 6 } & Sogur i wsp. (2009) & 90,66 & 70 & 90 & 35 \\
\hline
\end{tabular}

\section{Zmiany naczyniowe w przyzębiu okołowierzchołkowym}

Przykładem tego rodzaju mogą być zmiany pochodzenia naczyniowego - naczyniaki krwionośne, naczyniaki limfatyczne, hemangiopericytoma oraz angiosarcoma [11]. Przypadki te stanowią bardzo mały ułamek wszystkich zmian w przyzębiu okołowierzchołkowym, jednak ze względu na swoje niekiedy niezwykle poważne konsekwencje, powinny zostać wzięte pod uwagę $w$ diagnostyce różnicowej zmian zapalnych przyzębia okołowierzchołkowego [12].

Naczyniaki (haemangiomas) to łagodne guzy wywodzące się z naczyń krwionośnych, zaliczane do najczęstszych zmian rozrostowych. Szacuje się, że dotykają one ok. $10 \%$ populacji. Ich etiologia i patogeneza nadal są słabo poznane. Przyjmuje się, że przyczyną powstania tych zmian jest nieprawidłowy rozrost komórek śródbłonka naczyniowego w wyniku wrodzonego błędu w morfogenezie naczyń. W zależności od typu budowy naczyniaki można podzielić na włośniczkowe, jamiste i mieszane, a w zależności od typu naczyń na limfatyczne i krwionośne. Naczyniaki włośniczkowe najczęściej pojawiają się u dzieci, natomiast u dorosłych — jamiste [13]. Naczyniaki trzykrotnie częściej występują u dziewczynek. Do czynników ryzyka występowania zalicza się też ciążę wielopłodową, niską masę urodzeniową, wcześniactwo, inwazyjną diagnostykę prenatalną i rasę kaukaską; $60 \%$ guzów zlokalizowanych jest w obrębie głowy i szyi. Zajęcie warg i jamy ustnej stosunkowo często jest powikłane bolesnymi, trudno gojącymi się owrzodzeniami; duże naczyniaki warg mogą powodować wady zgryzu i wymowy [14]. Około $10 \%$ guzów osiąga znaczne rozmiary lub ma niekorzystną lokalizację, co może stanowić zagrożenie dla zdro- wia i życia. U około $80 \%$ chorych zmiany występuja pojedynczo, u 20\% lokalizacja jest wielomiejscowa. Zmianom mnogim mogą towarzyszyć naczyniaki narządów wewnętrznych, np. wątroby, mózgu, płuc. Zmiany mogące łudząco przypominać zapalenie przyzębia okołowierzchołkowego lokalizują się głównie w obrębie zębów trzonowych żuchwy [15]. Objawami tego rodzaju patologii jest przejaśnienie wokół wierzchołka sąsiadującego ze zmianą zęba, krwawienie ze szczeliny dziąsłowej, ruchomość zęba, ból oraz obrzęk dotkniętej nim okolicy.

Do badań diagnostycznych stosowanych w celu rozpoznania naczyniaków zalicza się ultrasonografię, konwencjonalne zdjęcia rentgenowskie, tomografię komputerową i rezonans magnetyczny [16]. W USG widoczne są jako hiperechogeniczne, owalne, ostro odgraniczone od środowiska zmiany. Mimo że są zbudowane $z$ dużej ilości małych naczyń, przepływ w nich jest bardzo wolny i niewykrywalny metodami dopplerowskimi. W RTG mogą występować pod postacią pogrubienia cienia tkanek miękkich. W tomografii komputerowej bez podania środka cieniującego naczyniaki są izo/ hipodensyjne i charakteryzują się silnym wzmocnieniem od obwodu po podaniu środka cieniującego, natomiast $\mathrm{w}$ rezonansie magnetycznym są izointensywne w obrazach T1-zależnych i silnie hiperintensywne w obrazach T2-zależnych. Znaczna większość naczyniaków nie wymaga leczenia, cechą charakterystyczną wyróżniającą je od innych guzów jest zdolność do samoistnej regresji.

Kolejnym rodzajem zmian są nowotwory określane jako hemangiopericytoma [11]. Mogą mieć one charakter łagodny lub złośliwy, mogą też wykazywać cechy pośrednie. Podobnie do naczyniaków krwionośnych i chłonnych, rozwijają się one 
częściej w obrębie żuchwy niż szczęki. Objawy kliniczne obejmują ból i obrzęk dotkniętej okolicy. W badaniach rtg widoczny jest obraz osteolizy z nieznacznym beleczkowaniem i obraz plastra miodu. Zmiany agresywne są źle odgraniczone i naruszają blaszkę zbitą kości [17].

Ostatnią grupą zmian mogących przypominać okołowierzchołkowe zmiany zapalne są naczyniakomięsaki (ang. angiosarcoma) [11]. Nowotwory te najczęściej rozwijają się w obrębie skóry, tkanek miękkich, w układzie rozrodczym, śledzionie, wątrobie, mózgu i kościach. Rzadko lokalizują się w obrębie kości, a pierwotne zmiany w obrębie jamy ustnej są niezwykle rzadkie i stanowią bardzo małą część wszystkich tego rodzaju nowotworów. W badaniu klinicznym widoczne mogą być jako źle odgraniczone i szybko powiększające się zmiany typu guzków o kształcie okrągłym lub owalnym, o kolorze czerwonawo-niebieskawym. W badaniu rtg zwykle widoczne jest jedno ognisko osteolizy oraz zmniejszenie grubości warstwy zbitej kości. W przypadku tych zmian niezwykle istotną rolę odgrywa odpowiednio wczesne wdrożenie leczenia w celu uniknięcia powikłań związanych z trudnościami w odbudowie protetycznej i utrzymaniu jakości życia pacjenta [18-21].

Szczególną uwagę $w$ procesie diagnostycznym $w$ trakcie badania stomatologicznego należy zwrócić na badanie żywotności miazgi. W przypadku stwierdzenia, że miazga jest żywa, nie należy wdrażać leczenia endodontycznego. Podstawą w codziennej praktyce klinicznej pozostają testy termiczne, jednak w przypadkach wątpliwych i trudniejszych przydatne okazać się mogą badania obiektywne, takie jak np. przepływometria Dopplerowska [22, 23]. Kluczowe jest wykonanie dalszej diagnostyki radiologicznej oraz histopatologicznej po konsultacji ze specjalistami radiologii i diagnostyki obrazowej oraz patomorfologii klinicznej. Zapobiec wówczas można niepotrzebnemu przedłużeniu procesu diagnostyczno-terapeutycznego oraz uniknąć przykrych dla pacjenta konsekwencji.

\section{Oświadczenia}

Oświadczenie dotyczące konfliktu interesów

Autorzy deklarują brak konfliktu interesów w autorstwie oraz publikacji pracy.

\section{Źródła finansowania}

Autorzy deklarują brak źródeł finansowania.

\section{Piśmiennictwo}

[1] Dominiak M, Łysiak K, Znamirowska A, Szczepański W, Hałoń A. Porównanie zgodności oceny klinicz- nej, histopatologicznej oraz radiologicznej przewlekłych zmian okołowierzchołkowych. Dent Med Probl. 2006;43(4):504-10.

[2] Wesselink PR. The incidental discovery of apical periodontitis. Endod Top. 2014;30(1):23-8.

[3] Abbott P V. Classification, diagnosis and clinical manifestations of apical periodontitis. Endod Top. 2004;8(1):36-54.

[4] Jacobi-Gresser E, Schütt S, Huesker K, Von Baehr V. Methyl mercaptan and hydrogen sulfide products stimulate proinflammatory cytokines in patients with necrotic pulp tissue and endodontically treated teeth. J Biol Regul Homeost Agents. 2015;29(1):7384.

[5] Weissman J, Johnson JD, Anderson M, Hollender L, Huson T, Paranjpe A, i in. Association between the presence of apical periodontitis and clinical symptoms in endodontic patients using cone-beam computed tomography and periapical radiographs. J Endod. 2015;41(11):1824-9.

[6] Jonasson P, Kvist T. Diagnosis of apical periodontitis in root-filled teeth. Clin Dent Rev. 2018;2(1):15

[7] Kanagasingam S, Hussaini HM, Soo I, Baharin S, Ashar A, Patel S. Accuracy of single and parallax film and digital periapical radiographs in diagnosing apical periodontitis-a cadaver study. Int Endod J. 2017;50(5):427-36.

[8] Krzyżostaniak J, Surdacka A. Rozwój i zastosowanie tomografii wolumetrycznej CBCT w diagnostyce stomatologicznej-przegląd piśmiennictwa. Dent Forum. 2010;2:83-8.

[9] Eliasz-Kaczmarek A, Surdacka A. Cone beam computed tomography imaging in clinical endodontics — Literature review. 2013;50(1):78-84.

[10] Patel S, Dawood A, Pitt Ford T, Whaites E. The potential applications of cone beam computed tomography in the management of endodontic problems. Int Endod J. 2007;40(10):818-30.

[11] Theodorou DJ, Theodorou SJ, Sartoris DJ. Primary non-odontogenic tumors of the jawbones: An overview of essential radiographic findings. Clin Imaging. 2003;27(1):59-70.

[12] Sirotheau Corrêa Pontes F, Paiva Fonseca F, Souza De Jesus A, Garcia Alves AC, Marques Araújo L, SiIva Do Nascimento $L, i$ in. Nonendodontic lesions misdiagnosed as apical periodontitis lesions: Series of case reports and review of literature. J Endod. 2014;40(1):16-27.

[13] Al-Holou WN, O'Lynnger TM, Pandey AS, Gemmete JJ, Thompson BG, Muraszko KM, i in. Natural history and imaging prevalence of cavernous malformations in children and young adults. J Neurosurg Pediatr. 2012;9(2):198-205.

[14] Buckmiller LM, Richter GT, Suen JY. Diagnosis and management of hemangiomas and vascular malformations of the head and neck. Oral Dis. 2010;16(5):405-18.

[15] Oliveira GG, García-Rozado A, Rey RL. Intraosseous mandibular hemangioma. A case report and review of the literature. Med Oral Patol Oral Cir Bucal. 2008;13(8):496-8. 
[16] Bhat V, Salins PC, Bhat V. Imaging spectrum of hemangioma and vascular malformations of the head and neck in children and adolescents. J Clin Imaging Sci. 2014;4.

[17] Routray S, Mohanty N, Panda S, Sahoo SR. Hemangiopericytoma/solitary fibrous tumor of mandible: A rare entity. J Oral Maxillofac Pathol. 2015;19(2):260-2.

[18] Loudon JA, Billy ML, DeYoung BR, Allen CM. Angiosarcoma of the mandible: a case report and review of the literature. Oral Surgery, Oral Med Oral Pathol Oral Radiol Endodontology. 2000;89(4):471-6.

[19] Nagata M, Yoshitake Y, Nakayama H, Yoshida R, Kawahara K, Nakagawa Y, i in. Angiosarcoma of the oral cavity: a clinicopathological study and a review of the literature. Int J Oral Maxillofac Surg. 2014;43(8):917-23.

[20] Doeuk C, McNamara Z, Taheri T, Batstone MD. Primary angiosarcoma of the mandible: a case report. J Oral Maxillofac Surg. 2014;72(12):2499-e1.

[21] Hunasgi S, Koneru A, Vanishree M, Manvikar V. Angiosarcoma of Anterior Mandibular Gingiva Showing Recurrence-A Case Report with Immunohistochemistry. J Clin diagnostic Res JCDR. 2016;10(7):ZD01.
[22] Eliasz W. Wykorzystanie laserowej przepływometrii dopplerowskiej w diagnostyce stanu miazgi i tkanek okołowierzchołkowych - opis przypadku. Dent Forum. 2019;47(1):52-6.

[23] Bober P, Eliasz W, Surdacka A. Zastosowanie przepływomierza Dopplera w endodoncji i traumatologii stomatologicznej. W: Fizykodiagnostyka i rehabilitacja w medycynie i stomatologii - nowe trendy. 2017. s. $143-54$.

Zaakceptowano do edycji: 2020-06-01 Zaakceptowano do publikacji: 2020-06-15

\author{
Adres do korespondencji: \\ Wojciech Eliasz \\ Katedra i Klinika Stomatologii Zachowawczej \\ i Endodoncji, Uniwersytet Medyczny im. Karola \\ Marcinkowskiego w Poznaniu \\ ul. Bukowska 70, 60-812 Poznań \\ tel.: 618547027 \\ e-mail:weliasz@ump.edu.pl
}

